\title{
EXERCISE TRAINING REVERSES THE DELETERIOUS EFFECT OF SUCROSE INTAKE ON INSULIN RESISTANCE AND VISCERAL FAT MASS DEPOSITION ON MICE
}

\author{
${ }^{1}$ Julio Cesar Mendes Soares, ${ }^{2}$ Vanderlei Folmer, ${ }^{3}$ Gustavo Puntel and João B.T. Da Rocha \\ ${ }^{1}$ Universidade Federal do Pampa-UNIPAMPA-Campus de Itaqui RS, Brasil \\ ${ }^{2}$ Universidade Federal do Pampa-UNIPAMPA-Campus de Uruguaiana RS, Brasil \\ ${ }^{3-4}$ Departmento de Química,Universidade Federal de Santa Maria, Brasil
}

Received 2014-01-29; Revised 2014-03-01; Accepted 2014-03-28

\begin{abstract}
Abnormal fat deposition has been identified as an important mechanism of obesity-associated with insulin resistance. Literature data also indicate that exercise can improve insulin action. The heme pathway enzyme $\delta$ Aminolevulinate Dehydratase $(\boldsymbol{\delta}$-ALA-D) is a good marker for oxidative stress and this sulfhydryl enzyme is inhibited in such oxidative pathologies diabetes. The aim of this study was to evaluate the effects of physical exercise in mice fed high sucrose ( $20 \%$ in drinking water), on aspects of insulin resistance, profile of oxidative status in different tissues and influence on $\delta$-ALA-D activity. Glucose $(p<0.003)$, insulin $(p<0.01)$ plasma levels and abdominal fat index $(\mathrm{p}<0.001)$ were significantly higher in mice fed the sucrose in the water when compared to control group. Not have difference on these parameters between exercised mice fed the sucrose and control group. Hepatic, ALA-D activity and TBARS from liver, kidney and brain, of sucrose fed animals with and without exercise were not different than that of control group. The results of the present study possibly indicate that the sucrose administration in the water, cause marked insulin resistance and that the physical exercise showed efficient in increase insulin sensibility in mice with insulin resistance.
\end{abstract}

Keywords: Deleterious Effect, Sucrose, Visceral Fat, Mass Deposition

\section{INTRODUCTION}

Insulin resistance of skeletal muscle glucose transport represents a major defect in the normal maintenance of euglycemia (Henriksen, 2002). This insulin resistance is frequently accompanied by a variety of metabolic and cardiovascular abnormalities, including hypertension, glucose intolerance, Type 2 diabetes, dyslipidemia, atherosclerosis and central obesity, a condition referred to as "syndrome X" or the "insulin resistance syndrome" (Henriksen, 2002; Reaven, 1993). The link among these disorders has been attributed to hyperinsulinemia, a consequence of the insulin resistance (Henriksen, 2002). The obese rat is an animal model of severe skeletal muscle insulin resistance that is also characterized by marked hyperinsulinemia, glucose intolerance, dyslipidemia and central adiposity (Henriksen, 2002) and therefore is a suitable animal model of the insulin resistance syndrome. In a similar way to humans, feeding animals chronically with diets containing high proportion of rapidly absorbable glucose or with a high proportion of fat promotes the development of insulin resistance (Folmer et al., 2002).

Elevated levels of circulating glucose can produce permanent chemical alterations in proteins and increase lipid peroxidation in a variety of experimental models of hyperglycemia (Folmer et al., 2002). In line with this, overproduction of Reactive Oxygen Species (ROS) and antioxidant depletion have been associated with the onset of diabetes (Folmer et al., 2002). Oxidative stress has Ph: 021-55 3334-1669 
been implicated as a contributor to both the onset and the progression of diabetes and its associated complications (Styskal et al., 2012; Rains and Jain, 2011).

Furthermore, the deleterious effects of hyperglycemia on the properties of physiologically abundant proteins such as hemoglobin, albumin and collagen have been investigated (Soares et al., 2006).

Physical exercise induces a series of normal physiological and biochemical adaptations. Several metabolic factors can contribute to the improvements in glucose homeostasis that are seen after acute or chronic exercise and exercise training in individuals with insulin resistance (Henriksen, 2002). These adaptive responses include enhanced insulin action on the skeletal muscle glucose transport system, normalization of glycemia, normalization of an abnormal blood lipid profile (Henriksen, 2002; James et al., 1983) and decrease in oxidative stress (Senturk et al., 2001; Atalay and Laaksonen, 2002).

$\delta$-ALA-D is an essential enzyme for all aerobic organisms because it participates in the biosynthesis pathway of tetrapyrrole molecules, which constitute prosthetic groups of physiologically important proteins such as hemoglobin and cytochromes (Jaffe et al., 1995; Sassa, 1998). $\delta$-ALA-D is a sulfhydryl-containing enzyme; consequently, its activity is highly sensitive to the presence of prooxidant elements, which can oxidize its-SH groups (Barbosa et al., 1998; Soares et al., 2002; Maciel et al., 2000). Of particular importance is the impairment of the heme synthetic pathway in porphyria. The frequent coexistence of diabetes mellitus and porphyria disease has been reported in humans and experimental animal models (Scassa et al., 1998); this can be causally linked to the inhibition of this enzyme that occurs in diabetics (Caballero et al., 1995; Fernandez-Cuartero et al., 1999).

The aim of this study was to evaluate the effects of physical exercise in mice fed high sucrose $(20 \%$ in drinking water) on aspects of insulin resistance, profile of oxidative status in different tissues (brain, liver, kidney) and influence on $\delta$-ALA-D activity.

\section{MATERIAL AND METODS}

\subsection{Chemicals}

5-Aminolevulinic Acid (ALA), DL-Dithiothreitol (DTT) and Malondialdehyde (MDA) were obtained from Sigma (St. Louis, MO). Mono-and dibasic potassium phosphate, acetic acid, orthophosphoric acid, Tris buffer, sucose, trichloroacetic acid and sodium chloride were obtained from Merck (Rio de Janeiro, RJ, Brazil).

\subsection{Animals and Diets}

Male mice (3-month-old) weighing 25-30 g from our own breeding colony were maintained under controlled conditions of room temperature $\left(20-25^{\circ} \mathrm{C}\right)$ and under natural lighting. The animals were divided in four groups: Control group (cont), control exercised (Cont+Exer), sucrose exercised (Sucr+Exer) and sucrose (Sucr). Groups III and IV received a solution of $20 \%$ sucrose as water ad libitum. Commercial diets and water were given ad libitum and consume was measured daily.

\subsection{Training Program}

A special swim-training model was used. Mice were adapted to swim at $30^{\circ} \mathrm{C}$ at $4 \mathrm{~d} / \mathrm{wk}$ (rest on weekends and Wednesday) for $4 \mathrm{wk}$ before experimental training. During week 1 , mice swam 15 min. During week 2 to 4 , mice swam for 20, 30 and 40 min respectively with an extra weight fixed to the tail ( $3 \%$ of the animal's body weight). After this adaptation period, only the exercised groups were subjected to swim training for $26 \mathrm{wk}$ at $30^{\circ} \mathrm{C}$ for 40 mim, $4 \mathrm{~d} / \mathrm{wk}$ (rest on weekends and Wednesday) with the tail weight ( $3 \%$ of the animal's body weight).

\subsection{Tissue Preparation}

Mice were killed by decapitation. The liver was quickly removed, placed on ice and homogenized in seven volumes of cold $0.2 \mathrm{mM}$ BHT $+0.9 \% \mathrm{NaCl}$. The homogenate was centrifuged at $4000 \times \mathrm{g}$ at $4{ }^{\circ} \mathrm{C}$ for 10 min to yield a low-speed supernatant fraction (S1) that was used for biochemical assay.

\subsection{Biochemical Assay}

\subsubsection{All Experiments were Performed in Duplicate}

$\delta$-ALA-D activity was assayed by the method of (Sassa, 1982) by measuring the rate of Product (PBG) formation except that $84 \mathrm{mM}$ potassium phosphate buffer, pH 6.4 and $2.4 \mathrm{mM}$ ALA were used (Emanuelli et al., 1996; Rocha et al., 1995). All experiments were carried out after $10 \mathrm{~min}$ of pre-incubation. The reaction was started $10 \mathrm{~min}$ after the addition of the enzyme preparation by adding the substrate. Incubation was carried out for $1 \mathrm{~h}$ at 39.C the reaction product was determined using modified Ehrlich's reagent at 555 $\mathrm{nm}$, with a molar absorption coefficient of $6.1 \times 104$ M.1 for the Ehrlich-PBG salt. The reaction rates were linear with respect to time of incubation and added protein for all experimental conditions. 
Thiobarbituric Acid Reactive Species (TBA-RS) were determined according to Ohkawa et al. (1979). Briefly, the reaction mixture contained $100 \mu \mathrm{L} 8.1 \%$ SDS, $200 \mu \mathrm{L}$ low-speed supernatant fraction (S1), 750 $\mu \mathrm{L} 1.267 \mathrm{moL} / \mathrm{L}$ acetic acid, $270 \mathrm{mmoL} / \mathrm{L} \mathrm{HCl}, \mathrm{pH} 3.5$ and $750 \mu \mathrm{L} 0.8 \%$ TBA. TBA-RS were quantified by adding $S 1$ directly to the above reaction medium. Samples were incubated at 100.C for $60 \mathrm{~min}$ and then centrifuged at $1000 \times \mathrm{g}$ for $15 \mathrm{~min}$ at 4 .C. The amount of TBA-RS produced was measured at $532 \mathrm{~nm}$, using MDA to construct standard curves.

Protein was measured by the method of Bradford (1976) using bovine serum albumin as standard. Following collection, blood samples were transferred to polypropylene tubes containing EDTA $\left(12 \mathrm{mg} \mathrm{mL}^{-1}\right)$ and stored on ice. Plasma samples were harvested by centrifugation and stored frozen until the time for assay. Glucose was measured with commercial kits using enzymatic methods (Labtest, Minas Gerais, Brazil) and plasma insulin was measured by radioimmunoassay (Linco Research, St. Charles, MO).

\subsection{Statistical Analysis}

Data were analyzed by one-way ANOVA, followed by Duncan's multiple range test when appropriate. Differences between groups were considered to be significant when $\mathrm{p} \leq 0.05$.

\section{RESULTS}

\subsection{Body Weight Gain}

The body weight of the mice fed with solution of sucrose was significantly greater than that of the mice of the control group after the 6-wk up to 26-wk $(\mathrm{p}<0.001)$. After the 10-wk up to 26-wk experiment the body weight of the mice from exercised and exercised+sucrose groups were lower than that of the mice of the control group $(\mathrm{p}<0.001)$ Fig. 1.

\subsection{Food Consumption}

The consumption of food by the mice groups on sucrose were significantly lower than that of the mice of the control group after the 4-wk experiment and this persisted until the final period of experiment $(p<0.001$ for Suc or Suc+Exc groups) Fig. 2.

\subsection{Insulin and Glucose Levels}

The insulin plasmatic levels was significantly higher in mice fed the sucrose in the water than in those groups that did not receive sucrose $(\mathrm{p}<0.001)$. The insulin levels in exercised mice fed the sucrose in the water was similar to that of control groups (Cont and Cont-Exer) Fig. 3A. Similarly, glucose plasmatic levels in mice fed with high sucrose in the water was significantly higher than those of mice of control (Cont and Cont-Exer) and Sucr-Exerc groups $(\mathrm{p}<0.01)$ Fig. 3B.

\subsection{Abdominal Fat Index}

The mice feeding with solution of sucrose presented abdominal fat index significantly greater than that of the mice of the other groups (Cont, Cont-Exer and SucrExer $)(p<0.001)$ Fig. 4.

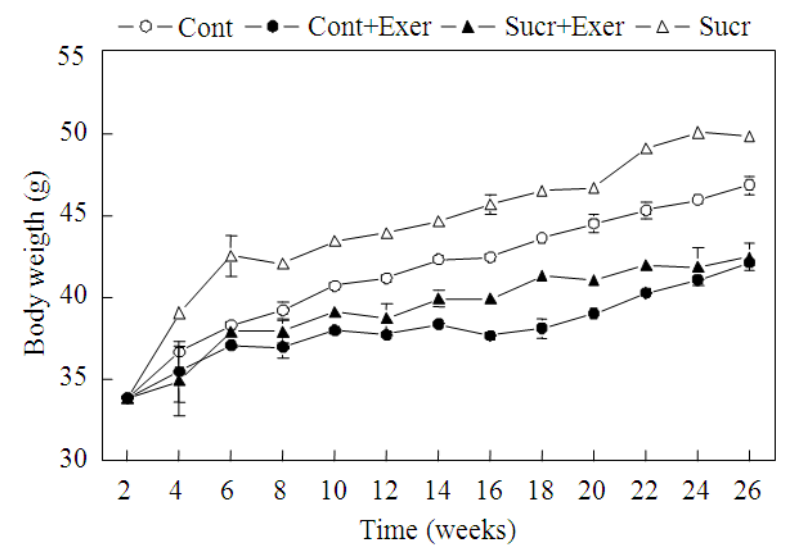

Fig. 1. Weight gain in mice of the control group (Cont $\circ$ ), exercised (Cont+Exer •), fed high sucrose and exercised (Sucr+Exer $\mathbf{\Delta}$ ) and only fed high sucrose $($ Sucr $\Delta)$ diets for $26 \mathrm{wk}$. Values are means $\pm \mathrm{SD}, \mathrm{n}=10$ per group. *Different from control, $(\mathrm{p}<0.00)$

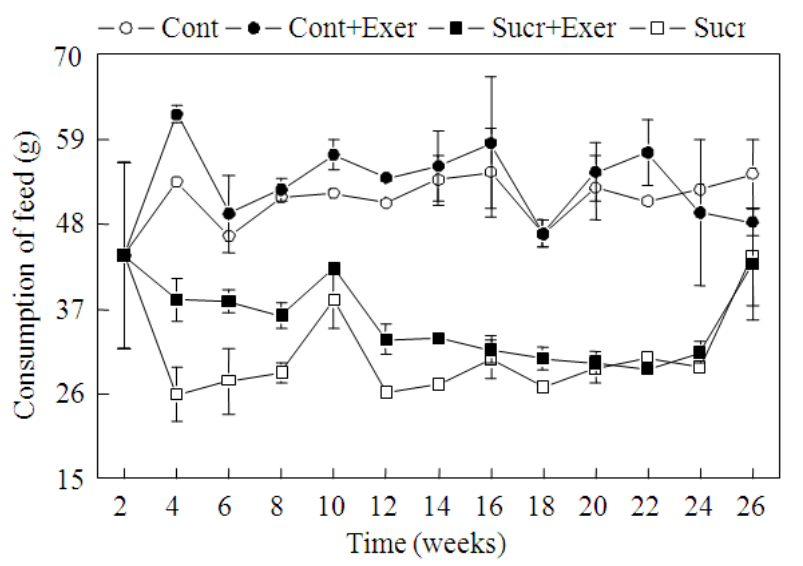

Fig. 2. Consumption of feed in the mice of the control group $($ Cont $\circ$ ), exercised (Cont+Exer $\bullet$ ), fed high sucrose and exercised (Sucr+Exer $\boldsymbol{\Delta}$ ) and only fed high sucrose $($ Sucr $\Delta)$ diets for $26 \mathrm{wk}$. Values are means $\pm \mathrm{SD}, \mathrm{n}=10$ per group. *Different from control, $(\mathrm{p}<0.00)$ 
Julio Cesar Mendes Soares et al. / American Journal of Biochemistry and Biotechnology 10 (1): 50-57, 2014

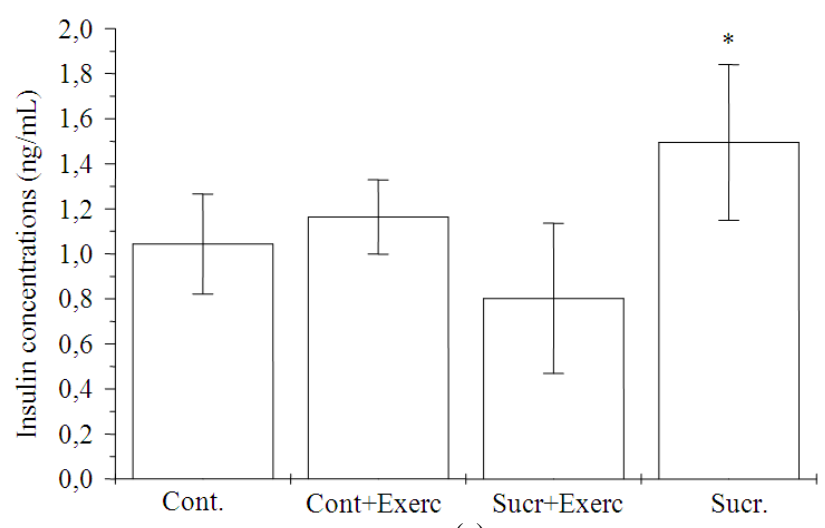

(a)

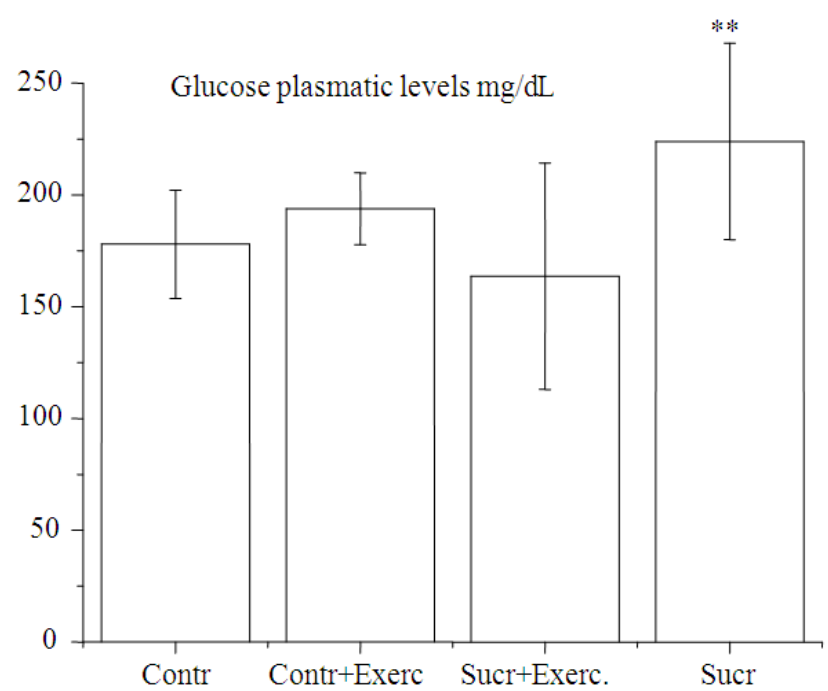

(b)

Fig. 3. Plasma insulin (3A) and glucose (3B) concentrations in mice after a 12-h period of starvation. Animals of the control group (Cont), exercised (Cont+Exer), fed high sucrose and exercised (Sucr+Exer) and only fed high sucrose (Sucr) diets for 26 wk. Results are expressed as mean \pm SD. for ten animals per group $(* p<0.001$ and $* * p<0.01)$

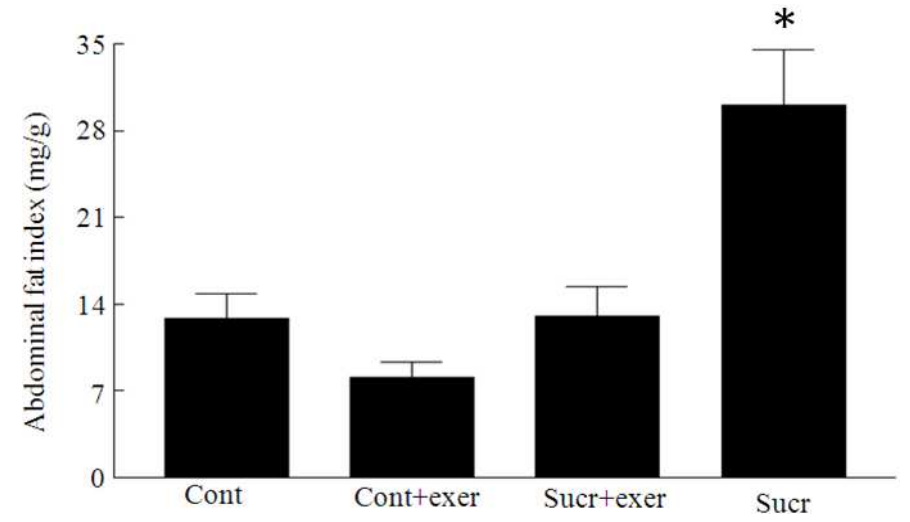

Fig. 4. Abdominal index fat in the mice of the control group (Cont), exercised (Cont+Exer), fed high sucrose and exercised (Sucr+Exer) and only fed high sucrose (Sucr) diets for 26 wk. Values are means $\pm S D, n=10$ per group. *Different from control, $(\mathrm{p}<0.00)$ 


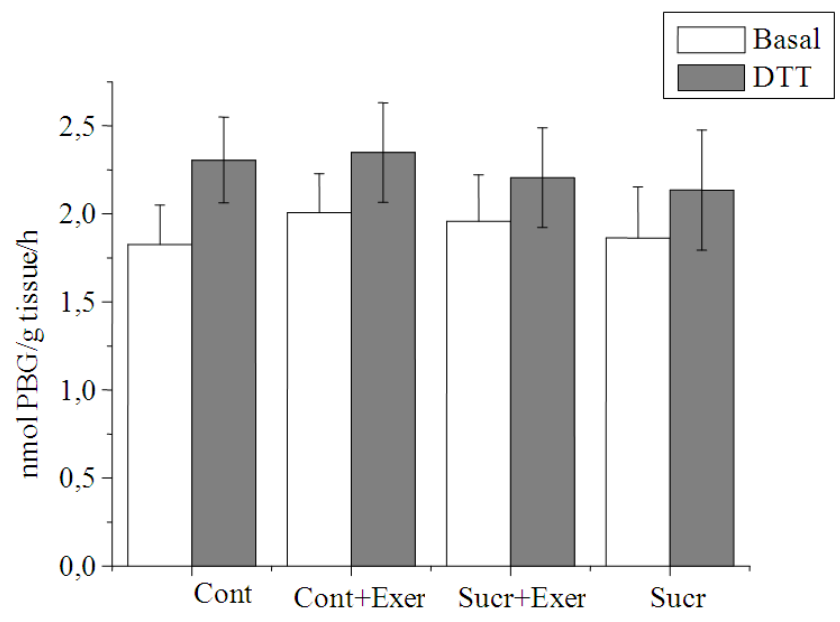

Fig. 5. $\delta$-ALA-D activity in liver in the absence or the presence of DTT ( $2 \mathrm{mmol} / \mathrm{L})$. Data are expressed as mean \pm SD for $8-10$ animals per group

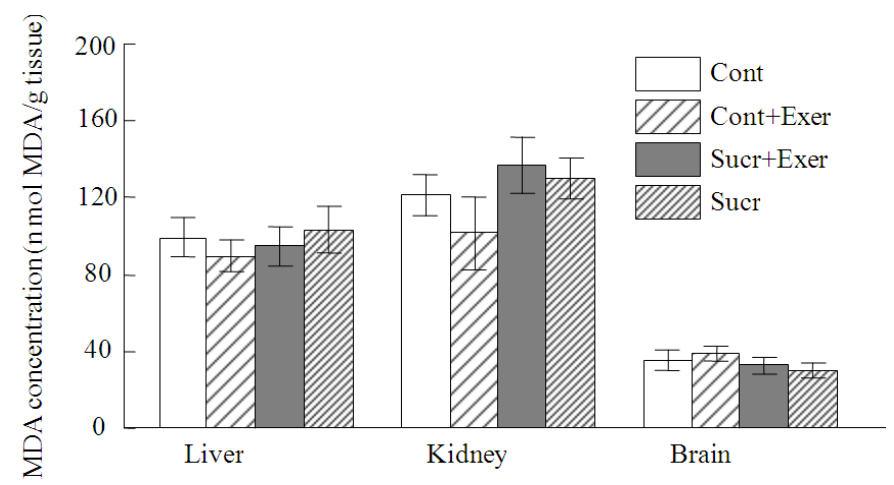

Fig. 6. Basal tba-rs levels in liver, kidney and brain tissues of mice of the control (Cont), exercised (Cont+Exer), fed high sucrose and exercised (Sucr+Exer) and only fed high sucrose (Sucr) diets for $26 \mathrm{wk}$. Results are expressed as mean \pm SD. for ten animals per group

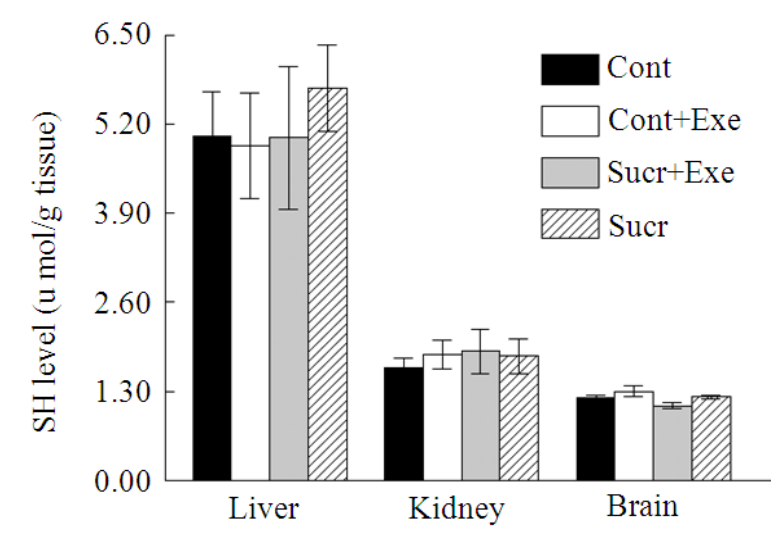

Fig. 7. Levels of NPSH groups from liver, kidney and brain tissues of mice of the control (Cont), exercised (Cont+Exer), fed high sucrose and exercised (Sucr+Exer) and only fed high sucrose (Sucr) diets for $26 \mathrm{wk}$. Results are expressed as mean \pm SD for ten animals per group 


\section{5. $\delta$-ALA-D Activity}

Liver $\delta$-ALA-D activity of sucrose fed animals with and without exercise was not different from that of control groups. Addition of DTT $(2 \mathrm{mmoL})$ increased $\delta$ ALA-D activity; however, this increase was similar for all groups Fig. 5.

\subsection{Tissues Tba-rs Levels}

Basal tba-rs levels in hepatic, renal and cerebral tissues of mice fed with sucrose in the water with and without exercise were not different from that of control groups Fig. 6.

\subsection{Tissues Non-Protein SH Groups Levels}

Non-protein SH groups from liver, kidney and brain tissues of mice was similar among the different treatment groups Fig. 7.

\section{DISCUSSION}

Chronic intake of diets with a high proportion of rapidly absorbable glucose promotes the development of insulin resistance (Folmer et al., 2002). In the present study, the insulin and plasmatic glucose levels were significantly higher in mice fed the sucrose in the water than in those that did not receive sucrose. Similarly, a high fat abdominal index was encountered in this group. These parameters characterize a classical index of insulin resistance. Visceral and intramuscular fat accumulation have been implicated in the development of insulin resistance in obese and type 2 diabetes subjects and, in line with this, literature data indicate that visceral fat excess is a good marker for insulin resistance (Wolfgram et al. 2014; Pavankumar and Nicola, 2013; Greco et al., 2002; Gutierrez et al., 2014; DM, 2014; Zhang et al., 2014; Snel et al., 2012).

Physical exercises have been reported as an important factor that can increase insulin responsiveness by tissues (Snel et al., 2012; Stuart et al., 2013; Hecksteden et al., 2013). The results of the present investigation clearly demonstrated that exercise re-established all the alterations caused by a high sucrose diet and returned to control levels the abdominal fat, glucose and insulin in a mice model of diet-induced insulin resistance.

The results are essentially similar to those from human studies in which physical exercise has invariable beneficial effects causing decreased in body weight and visceral fat accumulation in relatively short time intervals (Henriksen, 2002; Stuart et al., 2013). Furthermore, the present results are also somewhat similar to those showing that physical exercise causes weight-loss and reduces the incidence of Type 2 diabetes in overweight men with impaired glucose tolerance (Stuart et al., 2013).

The aerobic exercise can significantly lower plasma glucose levels, owing to normal contraction induced stimulation of GLUT-4 glucose transporter translocation and glucose transport activity in insulin-resistant skeletal muscle. In fact, training induced enhancement of insulin action is associated with up regulation of specific components of the glucose transport system in insulinresistant muscle and includes increased protein expression of GLUT-4 and insulin receptor substrate1(Henriksen, 2002; Stuart et al., 2013).

Previously, we have observed that exhaustive exercise associated with selenium deficiency caused an inhibition of the sulfhydryl-containing enzyme $\delta$-ALA-D (Soares et al., 2002). The enzyme inhibition could be a consequence of oxidation of critical thiol groups of enzyme by ROS produced during exercise (Soares et al., 2002). Since there are indications in literature that high sucrose diets can induce oxidative stress in rodents, we sought to determine whether an association between exercise and sucrose could lead to an inhibition of the enzyme. However, we did not observe increase in lipoperoxidation cerebral, renal and hepatic tissues of mice fed high sucrose with or without exercise compared with those that did not receive sucrose in the water. In the same way, $\delta$-ALA-D activity and NPSH groups from hepatic tissue was not decreased by sucrose feeding or by exercise. The absence of effect of high sucrose feeding on liver ALA-D activity is accordance with previous observation from our laboratory.

Although physical exercise may acutely induce oxidative damage (Soares et al., 2011), regular training appears to enhance antioxidant defenses and may reduce oxidative stress after exercise and in some animal studies, it has been associated with a decreased lipid peroxidation (Atalay and Laaksonen, 2002; Laaksonen, 2003; Stanković and Radovanović, 2012). To maximize the benefits of exercise, it is important to understand the effect of acute and long term physical exercise on oxidative stress and antioxidant defenses in diabetes (Atalay and Laaksonen, 2002; Stanković and Radovanović, 2012). Some evidence also supports a role of physical fitness in decreasing lipid peroxidation (Laaksonen, 2003). If regular physical exercise can be shown to have a protective effect against oxidative stress (Stanković and Radovanović, 2012), this may have direct impact on the use of physical exercise as a safe therapeutic modality in diabetes (Atalay and Laaksonen, 2002; Laaksonen, 2003). 


\section{CONCLUSION}

The present results clearly indicated that moderate chronic exercise had favorable influence on the insulin resistance caused by feeding mice a highsucrose diet. The present results strongly indicate that exercise can be considered a good practice for obese subjects or for those that consume high quantities of free-sugar in the diet.

\section{ACKNOWLEDGEMENT}

The financial support by FAPERGS, CAPES and $\mathrm{CNPq}$ is gratefully acknowledged.

\section{REFERENCES}

Atalay, M. and D.E. Laaksonen, 2002. Diabetes, oxidative stress and physical exercise. J. Sports Sci. Med., 1: 1-14.

Barbosa, N.B.V., J.B.T. Rocha, G. Zeni, T. Emanuelli and M.C. Beque et al., 1998. Effect of organic forms of selenium on $\delta$-aminolevulinate dehydratase from liver, kidney and brain of adult rats. Toxicol. Applied Pharmacol., 149: 243-253. DOI: 10.1006/taap.1998.8373

Bradford, M.M., 1976. A rapid and sensitive method for the quantitation of microgram quantities of protein utilizing the principle of protein-dye binding. Anal. Biochem., 72: 248-254. DOI: 10.1016/00032697(76)90527-3

Caballero, F., E. Gerez, C. Polo, O. Mompo and E. Vazquez et al., 1995. Alteraciones en el camino metabólico del hemo en pacientes diabéticos/Changes in the heme metabolic pathway in diabetic patients. Medicina, 55: 117-124.

DM, 2014. Diabetic mice. Evidencex Med., 2014: 1-13.

Emanuelli, T., J.B.T. Rocha, M.E. Pereira, L.O. Porciuncula and V.M. Morsch et al., 1996. Effect of mercuric chloride intoxication and dimercaprol treatment on $\sigma$-aminolevulinate dehydratase from brain, liver and kidney of adult mice. Pharmacol. Toxicol., 79: 136-143. DOI: 10.1111/j.16000773.1996.tb00257.x

Fernandez-Cuartero, B., J.L. Rebollar, A. Batlle and R.E. Salamanca, 1999. Delta aminolevulinate dehydratase (ALA-D) activity in human and experimental diabetes mellitus. Int. J. Biochem. Cell Biol., 31: 479-488. DOI: 10.1016/S13572725(98)00145-9
Folmer, V., J.C.M. Soares and J.B.T. Rocha, 2002. Oxidative stress in mice is dependent on the free glucose content of the diet. Int. J. Biochem. Cell Biol., 34: 1279-1285. DOI: 10.1016/S13572725(02)00065-1

Greco, A.V., G. Giancaterini, A. Mingrone, M. Manco and M. Morroni et al., 2002. Insulin resistance in morbid obesity reversal with intramyocellular fat depletion. Diabetes, 51: 144-151. DOI: 10.2337/diabetes.51.1.144

Gutierrez, R.M.P., D.M. Ahuatzi, M.C. Horcacitas, E.G. Baez and T.C. Victoria et al., 2014. Antidiabetic effects of Carassius auratus complex formula in high fat diet combined streptozotocin-induced diabetic mice. Evidence-Based Complementary Alternative Med., 2014: 1-13. DOI: $10.1155 / 2014 / 628473$

Hecksteden, A., T. Grütters and T. Meyer, 2013. Associations between acute and chronic effects of exercise on indicators of metabolic health: A pilot training trial. Plos One, 8: 1-6. DOI: 10.1371/journal.pone.0081181

Henriksen, E.J., 2002. Invited review: Effects of acute exercise and exercise training on insulin resistance. J. Applied Physiol., 93: 788-796. PMID: 12133893

Jaffe, E.K., S. Ali, L.W. Mitchell, K.M. Taylor and M. Volin et al., 1995. Characterization of the role of the stimulatory magnesium of Escherichia coli porphobilinogen synthase. Biochemistry, 34: 244251. DOI: DOI: $10.1021 / \mathrm{bi00001a029}$

James, D.E., K.M. Burleigh, E.W. Kraegen and D.J. Chisholm, 1983. Effect of acute exercise and prolonged training on insulin response to intravenous glucose in vivo in rat. J. Applied Physiol., 55: 1660-1664. PMID: 6363362

Laaksonen, D.E., 2003. Role of physical exercise, fitness and aerobic training in type 1 diabetic and healthy men in relation to the lipid profile, lipid peroxidation and the metabolic syndrome. J. Sports Sci. Med., 2: 1-66.

Maciel, E.M., R.C. Bolzan, A.L. Braga and J.B.T. Rocha, 2000. Diphenyl diselenide and diphenyl ditelluride differentially affect delta-aminolevulinate dehydratase from liver, kidney and brain of mice. J. Biochem. Mol. Toxicol., 14: 310-319. PMID: 11083084

Ohkawa, H., N. Ohishi and K. Yagi, 1979. Assay for lipid peroxides in animal tissues by thiobarbituric acid reaction. Anal. Biochem., 95: 351-358. DOI: 10.1016/0003-2697(79)90738-3

Pavankumar, P. and A. Nicola, 2013. Body fat distribution and insulin resistance. Nutrients, 5: 2019-2027. DOI: 10.3390/nu5062019 
Rains, J.L. and S.K. Jain, 2011. Oxidative stress, insulin signaling and diabetes. Free Radic Biol. Med., 50: 567-575. 10.1016/j.freeradbiomed.2010.12.006

Reaven, G.M., 1993. Role of insulin resistance in human disease (Syndrome X): An expanded definition. Annu. Rev. Med., 44: 121-131. DOI: 10.1146/annurev.me.44.020193.001005

Rocha, J.B.T., M.E. Pereira, T. Emanuelli, R.S. Christofari and D.O. Souza,1995. Effect of treatment with mercury chloride and lead acetate during the second stage of rapid postnatal brain growth on $\delta$-aminolevulinic acid dehydratase (ALAD) activity in brain, liver, kidney and blood of suckling rats. Toxicology, 100: 27-37. DOI: 10.1016/0300-483X(95)03054-J

Sassa, S., 1998. ALAD porphyria. Semin. Liver Dis., 18: 95-101. DOI: $10.1055 / \mathrm{s}-2007-1007145$

Sassa, S.,1982. Delta-aminolevulinic acid dehydratase assay. Enzyme, 28: 133-145. PMID: 7140716

Scassa, M.E., C.L. Varone, L. Montero and E.T. Cánepa, 1998. Insulin inhibits $\delta$-aminolevulinate synthase gene expression in rat hepatocytes and human hepatoma cells. Exp. Cell. Res., 244: 460-469. DOI: 10.1006/excr.1998.4206

Senturk, U.K., F. Gunduz, O. Kuru, M. Aktekin and D. Kipmen et al., 2001. Exercise-induced oxidative stress affects erythrocytes in sedentary rats but not exercise-trained rats. J. Applied Physiol., 91: 19992004. PMID: 11641336

Snel, M., J.T. Jonker, J. Schoones, H. Lamb and A. Roos et al., 2012 Ectopic Fat and insulin resistance: Pathophysiology and effect of diet and lifestyle interventions. Int. J. Endocrinol., 2012: 1-18. DOI: $10.1155 / 2012 / 983814$

Soares, J.C.M., D. Gabriel, V. Folmer, G.R. Augusti and J.B.T. Rocha, 2006. High concentrations of glucose can activate or inhibit human erythrocyte aminolevulinate dehydratase in vitro depending exposure time. Am. J. Biotechem. Biotechnol., 2:180185. DOI: $10.3844 / a j b b s p .2006 .180 .185$
Soares, J.C.M., R. Zanella, B. Bondan, L.P. Alves and M.R. Lima et al., 2011. Biochemical and antioxidant changes in plasma, serum and erythrocytes of horses before and after a jumping competition. Equine Vet. Sci. J. Equine Vet. Sci., 31: 357-360. DOI: 10.1016/j.jevs.2011.03.017

Soares, J.C.M., V. Folmer and J.B.T. Rocha, 2002. Influence of dietary selenium supplementation and exercise on thiol-containing enzymes in mice. Nutrition, 19: 627-632. DOI: 10.1016/S08999007(03)00065-0

Stanković, M. and D. Radovanović, 2012. Oxidative stress and physical activity. SportLogia, 8: 1-11. DOI: 10.5550/sgia.120801.en.001S

Stuart, C.A., M.A. South, M.L. Lee, M.P. McCurry and M.E. Howell et al., 2013. Insulin responsiveness in metabolic syndrome after eight weeks of cycle training. Med. Sci. Sports Exerc., 45: 2021-2029. DOI: 10.1249/MSS.0b013e31829a6ce8

Styskal, J., H.V. Remmen, A. Richardson and A.B. Salmon, 2012. Oxidative stress and diabetes: What can we learn about insulin resistance from antioxidant mutant mouse models? Free Radic Biol. Med., 52: 46-58. DOI: 10.1016/j.freeradbiomed.2011.10.441

Wolfgram, P.M., E.L. Connor, J.L. Rehm, J.C. Eickhoff and S.B. Reeder et al. 2014. Ethnic differences in the effects of hepatic fat deposition on insulin resistance in nonobese middle school girls. Obesity, 22: 243-248. DOI: 10.1002/oby. 20521

Zhang, T., S. Zhao, W. Li, L. Ma, M. Ding and R. Li et al., 2014. High-fat diet from perilla oil induces insulin resistance despite lower serum lipids and increases hepatic fatty acid oxidation in rats. Lipids Health Dis., 13: 1-15. DOI: 10.1186/1476511X-13-15 